\title{
The Effect of Sex Education on Premarital Sex Among Adolescents; Literature Review
}

\author{
Putri Eka Sejati, Riza \\ Tsalatsatul Mufida \\ Institute of Health Sciences \\ Strada Indonesia \\ Email: \\ putridanialin@gmail.com
}

Received: October $4^{\text {nd }} 2021$

Accepted : October $15^{\text {rd }} 2021$

Published : November $27^{\text {th }} 2021$

\begin{abstract}
Adolescent are an age group that is vulnerable to risky behaviour, including premarital sex, because during adolescent there are various changes both physically, namely the maturation of reproductive organs, emotional changes in attitudes and behaviour as well adolescent mind-sets and social changes. Vulnerable to engage risky behaviour (premarital sex behaviour). Lack of sex education and the misconception of the concept of sex education regarding premarital sex which is misunderstood causes various negative problems is adolescent.

Sex education is a preventive effort to avoid free sex to damage reproductive health and mental unpreparedness in living their days a parents. So it needs extra education so that there is no misunderstanding of the concept of sex education material. The purpose of this paper is to determine the effect of sex education on premarital sex.

This literature review is sourced from the Pubmed and Google Scholar database from 2017-2021 and manually select criteria according o the inclusion and exclusion criteria using the PICOS method, which is relevant and in accordance with the title taken by the author, in this literature review the number of journals reviewed by 8 journals. The result of this literature review found that the effects of sex education on premarital sex include, the lack of knowledge about sex education causes adolescents to take premarital sexual behaviour, imperfect socialization, misunderstanding about of the concept of sex education on premarital sex, strong curiosity and some people think taboo about the concept of sex education. the conclusion in this literature review is the effect of sex education on behaviour sex, namely low knowledge, misunderstanding of the concept of sex education and imperfect socialization, not only from school but the role of the family is needed to instil sex education to reduce sexual behaviour premarital sex in adolescent.
\end{abstract}

Keywords: Sex education, premarital sex

Copyright (C) 2021 IIK STRADA Indonesia All right reserved.

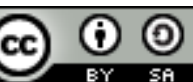

This is an open-acces article distributed under the terms of the Creative Commons AttributionShareAlike 4.0 International License. 


\section{INTRODUCTION}

The World Health Organization (WHO) defines adolescents as individuals aged 10-19 years, while the United Nations defines young people as 15-24 years old. Adolescence is a transition from childhood to adulthood so it is called a crucial period in which adolescents will be faced with several problems, one of which is premarital sex which can lead to teenage pregnancy and sexually transmitted infections (STDs) .

During the developmental period, adolescents begin to like the opposite sex, like challenges and tend to dare to take risks without being preceded by careful thought. This condition can place adolescents in a vulnerable condition if they are not provided with correct information regarding mental processes and adolescent health. Many adolescent problems occur such as violence, alcohol abuse, and smoking. However, the most vulnerable to occur in adolescent problems is premarital sex behaviour (Rahardjo et al., 2017) ${ }^{(2)}$ Premarital sexual behaviour can have negative impacts afterward, such as unwanted pregnancy (KTD), to abortion (Astuti, 2017)

According to Komnas Perempuan's 2018 annual records dated March 7 2018, it was found that the incidence of forced sexual behaviour was more experienced by unmarried women at the age of teenagers or high school equivalents, namely 34.4\%. In the Data Centre for Disease and Prevention, the prevalence of adolescents having premarital sex is $41 \%$ and this figure shows an increasing trend from year to year. This also happened in Indonesia, supported by a survey that the prevalence of adolescents who had premarital sex was $4.5 \%$ for men and $0.7 \%$ for women. In the 2017 IDHS survey, $50 \%$ of adolescent boys and $30 \%$ of girls admitted to having had sexual intercourse. Adolescent sexual behaviour was found to be $4.92 \%$ of adolescents who had sexually active behaviour, namely $56.9 \%$ had kissing, $30.7 \%$ necking, $13.8 \%$ petting, $7.2 \%$ oral sex, $5.5 \%$ anal sex, and $14.7 \%$ had intercourse. ${ }^{(3)}$

The lack of sex education in adolescents makes children more curious and chooses to seek information about sex through the internet, where the information they get is not filtered and even inappropriate for them to digest, such as pornographic images, adult stories and even videos showing husband and wife relationships. (Awaru, Idris \& Agustang, 2018) Lack of sex education will lead children to free sex, as we know free sex is very bad for a person's life. ${ }^{(4)}$

The purpose of this study was to determine the effect of sex education on premarital sex behavior in adolescents

\section{MATERIALS AND METHODS}

In this study using a Literature review sourced from the Pubmed and Google Scholar databases from 2017-2021 and manually selecting criteria according to the inclusion and exclusion criteria using the PICOS method, which is relevant and in accordance with the title taken by the author, in this literature review the number of reviewed journals as many as 9 journals

\section{RESULTS}

The research results from this literature review, the authors use a number of 9 journals, namely national journals and international journals.

The results of the 1st journal research (Ariska \& Yuliana, 2021) found that if an individual does not have good knowledge, then they will fail to understand something they get from various inappropriate electronic media. this will cause individuals to be more curious and find out so that they fail to understand and do things that deviate. They will be stuck in a comfortable situation and will follow the flow of current trends such as homosexuals, party sex and so on.

The results of the 2nd journal research (Chanif Kurnia Sari, 2019) found that reproductive health education had a positive impact on changing knowledge from not knowing to knowing. Many slight changes in knowledge can be caused by several things, one of which is the participant factor itself or the health education process carried out.

The results of the 3rd journal research according to (Ansari et al., 2020). Information obtained from comic media can increase information about adolescent sexuality, subjective norms and adolescent intentions not to engage in premarital sexual behavior.

The results of the 4th journal research from the results of the study (Dian Ayu Lestari, 2020), if individuals do not have good knowledge, then it is likely that they will fail to understand something they get as well as other information that is not appropriate, so they will be more curious and find out what can lead to deviant actions.

The results of the 5th journal research (Sukma et al., 2018), the result of a lack of understanding of sex education will cause teenagers to have premarital sex without understanding the risks that will occur. 
This happens because people assume that sex education is a very taboo thing to learn. There needs to be strong socialization to change people's mind-sets because sex education is very mandatory and important to understand for teenagers.

The results of the 6th journal research can be obtained that there is no relationship between knowledge, economy, cultural values, lifestyle and family and social support with adolescent premarital sexual behaviour. (Untari, 2017) A policy and regulation that applies in the youth environment will affect the behaviour of the teenager.

The results of the 7th journal research (Amartha et al., 2018) can be concluded that most teenagers are already dating and are at high risk of engaging in premarital sexual behaviour. Most teenagers do not understand the impact and risks of sexual behaviour. So it would be better if given counselling about sexual assertiveness so that they are able to control premarital sexual behaviour.

The results of the 8th journal (Aggasi, 2020) can be concluded that all students are familiar with the meaning of the word sex itself. Not a few of them have been able to explain about sexuality. One student said that compared to women, men tend to be more aggressive when starting sex for the first time.

The results of the 9th journal (Mostert et al., 2020) can be concluded that the level of sexual activity is low among adolescents. However, many adolescents engage in unsafe sexual activities due to inconsistent use of contraceptives, this happens because most adolescents are not sexually active, accompanied by a low level of adolescent knowledge related to sexuality.

\section{DISCUSSION}

One of the triggers for the influence of sex education on premarital sex is a great sense of curiosity and love to try something new. If this is not balanced with strong knowledge and proper education about sexual education and reproductive health, it is feared that unwanted effects can occur on adolescent sexual behaviour. Sexual behaviour is influenced by understanding of information related to sexual education and reproductive health. The small role of adolescent knowledge about sexual education on sexual behaviour is because it does not directly affect sexual behaviour. This is because adolescents who have begun to reach sexual maturity will find it difficult to control the stimuli that make them perform sexual behaviour freely without knowing the impact and risks that will occur to them.

There are deviations in premarital sex behaviour due to imperfect socialization received by individuals because of the individual's incomprehension to receive sexual education itself. Their knowledge of sex can be misused and will have a negative impact and cause curiosity. This curiosity is then searched through social media because the family environment is not supportive. This is the importance of proper sexual education and socialization of a strong understanding that they need to reduce curiosity and be able to control their own behaviour.

\section{CONCLUSION}

The lack of understanding and openness to the family, especially to parents, also triggers the influence of sex education itself. There is a wrong thought that considers sex education to have a bad impact and is something that is very taboo to study. Knowledge about sex education can run optimally if there is effective and quality communication in the family. In addition, this is also influenced by the background of the history of sex education they have received at the previous level. Many of them admit they have not and some have accepted.Website : http://jurnal.strada.ac.id/jqph Email : jqph@strada.ac.id

\section{REFERENCES}

PERILAKU SEKSUAL PRANIKAH MAHASISWA Science Humaniora. 4(2), 28-36.

Amartha, V. A., Fathimiyah, I., Rahayuwati, L., \& Rafiyah, I. (2018). Pendidikan

Kesehatan Mengenai Pencegahan Perilaku Seksual melalui Peningkatan Asertivitas pada Remaja Putri SMK Baabul Kamil Jatinangor. Media Karya Kesehatan, 1(1), 59-68. https://doi.org/10.24198/mkk.v1i1.17285 Ansari, R., Suwarni, L., Selviana, S., Mawardi, M., \& Rochmawati, R. (2020). Media Komik Sebagai Alternatif Media Promosi Kesehatan Seksualitas Remaja. Jurnal Ilmiah Kesehatan, 19(01), 10-14. https://doi.org/10.33221/jikes.v19i01.431

Ariska, A., \& Yuliana, N. (2021). Hubungan Tingkat Pengetahuan Remaja tentang Kesehatan Reproduksi dengan Sikap terhadap Perilaku Seksual Pranikah di SMP N 2 Jatipuro Relationships between Levels of Knowledge of Reproductive Health with Attitude to the Premarital Sexual Behavior Among Ado. Stethoscope, 1(2), 138-144. 
Chanif Kurnia Sari, I. D. (2019). Pendidikan Kesehatan Reproduksi Terhadap Pengetahuan Seks Bebas Remaja. Jurnal Delima Harapan, 6(2), 69-81.

Dian ayu lestari, J. H. (2020). Jurnal Sosialisasi SEKS REMAJA DI KECAMATAN MANGGALA KOTA MAKASSAR Jurnal Sosialisasi. 7, 21-28.

Mostert, K., Sethole, K. M., Khumisi, O., Peu, D., Tambura, J., Fisioterapi, D., Keperawatan, J. I., Radiografi, D., Sethole-, K. M., Khumisi-, O., Thambura-, J., Ngunyulu-, R. N., Mulaudzi-, M. F., \& Mostert, K. (2020). Email : 20, 28-38.

Sukma, A., Wijaya, Y., Khotijah, S. L., Ariani, P., Damayanti, B. A., \& Puspitasari, V. A. (2018). Tingkat Pemahaman Sex Education pada Mahasiswa Untidar Program Studi Pendidikan Biologi. Jurnal Pendidikan Biologi, 1(1), 7-11. https://jom.untidar.ac.id/index.php/nectar/article/view/980

Untari, A. D. (2017). Analisis Faktor yang Berhubungan dengan Perilaku Seks Pranikah pada Remaja yang Tinggal di Wilayah Eks Lokalisasi Berdasarkan Teori Transcultural Nursing. 1-94. 